\title{
Effects of an Angiotensin II Receptor Antagonist and Angiotensin-Converting Enzyme Inhibitors on Burst Forming Units-Erythroid in Chronic Hemodialysis Patients
}

\author{
Masayo Naito ${ }^{a}$ Akira Kawashima $^{\mathrm{b}}$ Takashi Akiba ${ }^{\mathrm{b}}$ Minoko Takanashic \\ Hiroshi Niheia
}

aDepartment of Internal Medicine and 'Division of Blood Purification, Kidney Center, Tokyo Women's Medical University, Tokyo, and 'Tokyo Metropolitan Red Cross Blood Center, Tokyo, Japan

\author{
Key Words \\ Erythropoiesis $\cdot$ Hemodialysis $\cdot$ Renin-angiotensin \\ system
}

\begin{abstract}
Background: Angiotensin-converting enzyme (ACE) inhibitors have been reported to reduce the response to erythropoietin (EPO) administration in chronic hemodialysis patients, but the mechanism for this effect has not yet been clarified. To clarify the mechanism of ACE inhibitors- and angiotensin II type 1 (AT1) receptor antagonistinduced anemia in hemodialysis patients, we examined the effect of ACE inhibitors and AT1 receptor antagonist on burst-forming units-erythroid (BFU-E) in the peripheral blood of hemodialysis patients and healthy controls in vitro. Methods: Peripheral blood mononuclear cells (PBMNCs) were isolated by gradient centrifugation from 10 patients on regular hemodialysis and 7 healthy control volunteers. A colony assay of hematopoietic progenitors was performed using the methylcellulose culture
\end{abstract}

The present work was conducted at Tokyo Metropolitan Red Cross Blood Center, Tokyo, Japan.

\section{KARGER}

Fax +41613061234

E-Mail karger@karger.ch

www.karger.com
(C) 2003 S. Karger AG, Basel

0250-8095/03/0235-0287\$19.50/0

Accessible online at:

www.karger.com/ajn system. PBMNCs of 1 or $2 \times 10^{5}$ were plated in a medium containing EPO with various concentrations of ACE inhibitors or AT1 receptor antagonist and incubated for 14 days. Colonies of BFU-E were counted under an inverted microscope. Results: The PBMNCs from the chronic hemodialysis patients formed fewer BFU-Es than those from healthy volunteers. AT1 receptor antagonist in both healthy volunteers and hemodialysis patients suppressed the number of BFU-Es. The ACE inhibitors produced a smaller effect than the AT1 receptor antagonist. Conclusion: AT1 receptor blockade can directly inhibit erythropoiesis in vitro.

Copyright $@ 2003$ S. Karger AG, Basel

\section{Introduction}

The use of angiotensin-converting enzyme (ACE) inhibitors in hemodialysis (HD) patients may significantly increase the need for erythropoietin (EPO) to maintain stable hematocrit levels [1-4]. ACE inhibitors have been known to further reduce hematocrit levels or worsen anemia in patients with renal insufficiency and renal transplant recipients [5-9]. Recently, angiotensin II receptor

Masayo Naito

Department of Internal Medicine, Kidney Center

Tokyo Women's Medical University

8-1 Kawada-cho, Sinjyuku-ku, Tokyo 162-8666 (Japan)

Tel. +81333538111 (39112), Fax +8133356 0293, E-Mail masayo.3.9@mbf.nifty.com 
antagonist has also been observed to exacerbate anemia in these patients $[10,11]$.

The destruction and alteration of red blood cells in the plasma is not affected by ACE inhibitor, and this is not the cause of the observed anemia [6]. Some studies indicate that ACE inhibitor appears to induce anemia by decreasing red cell production $[8,9]$. The renin-angiotensin system has been shown to stimulate EPO synthesis [12]. Many studies have reported that ACE inhibitors effectively inhibit erythrocytosis. The reduction of serum EPO levels is one of the proposed mechanisms by which ACE inhibitor reduces the hematocrit and causes anemia. ACE inhibitor has been suggested to reduce endogenous EPO production [3, 4, 8, 9]. However, other studies do not support this finding and have shown no changes in EPO levels, despite the development of anemia [1, 2, 5-7].

Thus, the precise mechanism by which ACE inhibitor interferes with hematopoiesis remains unclear. While the regulation of erythropoiesis is not fully understood, EPO is an obligatory growth factor that increases the number of progenitors by stimulating erythroid mitogenesis and differentiation and by preventing apoptosis. However, the proliferation of the earliest primitive erythroid progenitors depends on growth factors that are not unique to erythropoiesis, of which IL-3 and stem cell factor may dominate.

Angiotensin II, which has a mitogenic effect on smooth muscle cells, may be one of these additional factors that stimulates erythropoiesis, perhaps indirectly by increasing serum erythropoietin $[13,14]$. Angiotensin II type 1 (AT1) receptors were recently detected on red blood cell precursors, BFU-E-derived cells, and angiotensin II was suggested to possibly have a direct influence on erythropoiesis $[15,16]$.

To clarify how angiotensin II influences red blood cell production, we studied the dose response to ACE inhibitors (enalaprilat, trandprilate) and the AT1 receptor antagonist (losartan) as well as the relationship of EPO and angiotensin II to the proliferation of erythroid progenitors in chronic HD patients and controls.

\section{Subjects and Methods}

\section{Subjects}

We studied 7 healthy male volunteers (40-47 years), who were not receiving any medication and had normal blood pressure and hematocrit levels (43.2\% on average) and 10 male patients (41-49 years) with chronic renal failure (CRF), who were undergoing regular HD sessions three times a week (table 1). The age of the HD patients and the controls was not statistically significant. All of the HD
Table 1. Clinical characteristics and laboratory parameters of patients (mean $\pm \mathrm{SD}$ )

\begin{tabular}{lc}
\hline Patients & 10 \\
Age, years & $45.6 \pm 3.0$ \\
Sex, m/f & $10 / 0$ \\
Time on HD, months & $186.9 \pm 116.0$ \\
Etiology & glomerulonephritis \\
$\mathrm{BUN}, \mathrm{mg} / \mathrm{dl}$ & $74.8 \pm 23.0$ \\
$\mathrm{Cr}, \mathrm{mg} / \mathrm{dl}$ & $13.5 \pm 3.0$ \\
$\mathrm{Hb}, \mathrm{g} / \mathrm{dl}$ & $9.5 \pm 0.8$ \\
$\mathrm{Ht}, \%$ & $30.7 \pm 2.1$ \\
$\mathrm{Fe}, \mu \mathrm{d} / \mathrm{dl}$ & $54.3 \pm 23.6$ \\
$\mathrm{Ferritin}, \mu \mathrm{g} / \mathrm{dl}$ & $65.16 \pm 67.2$ \\
$\mathrm{I}-\mathrm{PTH}, \mathrm{pg} / \mathrm{ml}$ & $281 \pm 301$ \\
$\mathrm{KT} / \mathrm{V}$ & $1.12 \pm 0.31$ \\
\hline
\end{tabular}

patients had developed CRF because of chronic glomerulonephritis. The average hematocrit level of the patients was 30.7\%. Seven patients were treated with recombinant human EPO (r-HuEPO) at a mean dose of $4,285 \mathrm{IU} /$ week to maintain a hematocrit level of $30 \%$. All of these patients had received dialysis treatments for more than 3 months and showed no signs or symptoms of bacterial infection. They had not taken any of ACE inhibitor or AT1 receptor antagonist medication for at least 3 months prior to the time of peripheral blood (PB) collection. One fifth of them received an antihypertensive therapy. The patients were treated with the following agents: amlodipine, nifedipine, doxazosine, carvedilol. Patients with infection, iron deficiency, aluminum toxicity, and who were taking certain medications that could influence erythropoiesis were excluded from the study.

The study protocol was approved by the institutional human investigation committee, and informed consent was obtained from all participants or their legal guardians.

\section{Early Hematopoietic Progenitor Isolation and Cell Culture}

Circulating erythroid progenitor cells were isolated as described previously. Heparinized PB samples were obtained from the healthy volunteers and HD patients. All of PB samples were collected 44$68 \mathrm{~h}$ after the last EPO administration, directly before the HD procedure. Peripheral blood mononuclear cells (PBMNCs) were isolated by Ficoll-Paque (Pharmacia LKB, Biotechnology, Inc., Uppsala, Sweden)-Conray gradient centrifugation (specific gravity, $1.077 \mathrm{~g} /$ $\mathrm{ml}$ ) at $400 \mathrm{~g}$ for $30 \mathrm{~min}$. Cells were collected, washed twice with Iscove's modified Dulbecco's medium (IMDM; Life Technologies, Gaithersburg, Md., USA), and then resuspended in IMDM in 1 or $2 \times 10^{5} /$ dishes. A colony assay of hematopoietic progenitors was performed using a methylcellulose culture system (MethoCult GF H4434V; Stem Cell Technologies, Inc., Vancouver, B.C., Canada). These cultures were performed in the presence of $3 \mathrm{IU} / \mathrm{ml} \mathrm{r}-\mathrm{HuEPO}$, $50 \mathrm{ng} / \mathrm{ml} \mathrm{stem}$ cell factor, $10 \mathrm{ng} / \mathrm{ml} \mathrm{IL}-3,10 \mathrm{ng} / \mathrm{ml} \mathrm{GM}-\mathrm{CSF}$, and $17 \mathrm{ng} / \mathrm{ml} \mathrm{G}$-CSF. A total of 1 or $2 \times 10^{5}$ PBMNCs were plated in $35-\mathrm{mm}$ tissue culture dishes in a medium containing cytokines and incubated at $37^{\circ} \mathrm{C}$ in a humidified atmosphere containing $5 \% \mathrm{CO}_{2}$ for 14 days. The resulting BFU-E-derived colonies were counted under an inverted microscope. BFU-E was identified containing a minimum of three clusters or an equivalent amount of erythroblasts (>200 erythroblasts). 
Inhibition of BFU-E-Derived Erythroid Progenitor Proliferation

by AT1 Receptor Antagonist or ACE Inhibitors

PBMNCs were plated in a medium with various concentrations of the active metabolite of AT1 receptor antagonist or ACE inhibitors, respectively. Losartan (Merck \& Co, Inc., Linden, N.J., USA) was added at a concentration of $0,0.001,0.01,0.1,1$, or $10 \mu \mathrm{g} / \mathrm{ml}$. Trandolaprilate (Hoechst Marion Roussel, Romainville, France) was added at a concentration of $0,0.001,0.01,0.1$, or $1 \mu \mathrm{g} / \mathrm{ml}$. Enalaprilat (Merck \& Co) was added at a concentration of $0,0.001,0.01,0.1$, or $1 \mu \mathrm{g} / \mathrm{ml}$.

With regard to the range of effective blood levels, trandolaprilate was almost equipotent to enalaprilat. Dosages of $1 \mu \mathrm{g} / \mathrm{ml}$ of ACE inhibitors and $10 \mu \mathrm{g} / \mathrm{ml}$ of losartan were about ten times more potent than the range known to have an effect on blood levels.

The number of BFU-E colonies/dish $\left(2 \times 10^{5}\right.$ PBMNCs $)$ in the absence of all drugs was considered to be the baseline value, and the number of BFU-E colonies/dish $\left(2 \times 10^{5} \mathrm{PBMNCs}\right)$ was expressed as a percentage of that baseline value.

Effect of Angiotensin II and AT1 Receptor Antagonist or ACE Inhibitors on BFU-E-Derived Erythroid Progenitor Proliferation

The response of BFU-E to angiotensin II was determined using the Angiotensin II kit (Sigma Chemical Co., St. Louis, Mo., USA) and a concentration of $10^{-4} \mathrm{M}$. A dose-dependent effect was observed when the angiotensin II concentration ranged from $10^{-4}$ $10 M$. The concentrations of angiotensin II were selected based on a concentration response curve and were consistent with the growth response shown by Mrug et al. [15]. The concentrations of losartan and ACE inhibitors were selected as previously reported [15, 30]. So that they were about ten times more potent than the ranges known to clinically affect blood levels (ACE inhibitors, $1 \mu \mathrm{g} / \mathrm{ml}$; losartan, $10 \mu \mathrm{g} / \mathrm{ml}$ )

\section{Statistical Analysis}

All values are expressed as means $\pm \mathrm{SD}$, with statistical significance defined as a $\mathrm{p}$ value of $<0.05$. All statistical tests were performed using Excel computer software for Windows (Microsoft, Redmond, Wash., USA). A non-paired Student's t test was used to compare healthy volunteers and chronic HD patients. The responses at each drug concentration were compared using a two-way analysis of variance (ANOVA), followed by a multiple comparison post-hoc test.

\section{Results}

\section{Comparison of BFU-E Numbers in Chronic HD}

Patients and Controls

The PBMNC samples from the chronic HD patients and the healthy volunteers yielded $93.1 \pm 57.4$ and 435.6 \pm 94.8 BFU-E colonies/ $2 \times 10^{5}$ PBMNCs, respectively $(p<0.001)$ (fig. 1). No significant change was observed between the HD patients treated with or without r-HuEPO (125.5 \pm 73.5, 85.2 \pm 45.8 BFU-E colonies/ $2 \times 10^{5}$ PBMNCs, respectively). BFU-Es did not grow in the absence of EPO in either the patients or the controls. No increase in the number of BFU-E colonies was ob-

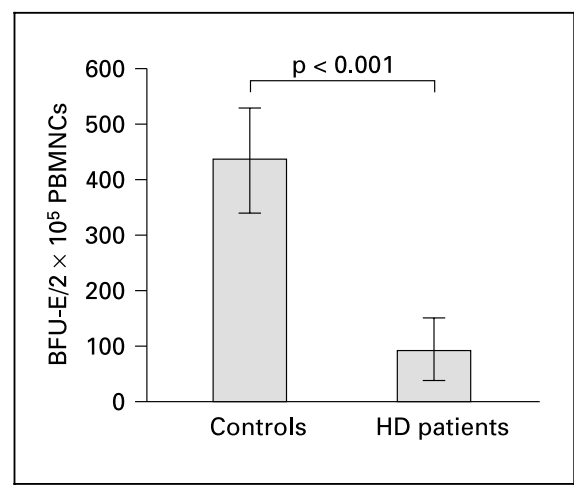

Fig. 1. Comparison of the number of BFU-E colonies in samples from chronic HD patients and controls. Healthy volunteers vs. chronic HD patients. Mean number \pm SD of BFU-E present in culture of $2 \times 10^{5}$ PBMNCs from controls and HD patients is shown. Statistically significant differences were observed for controls compared to HD patients. ${ }^{*} \mathrm{p}<0.001$; non-paired Student's t test. Values are shown as the mean $\pm \mathrm{SD}$.

served when higher EPO concentrations $>3 \mathrm{U} / \mathrm{ml}$ were added to the culture medium (data not shown).

\section{Effects of Losartan and ACE Inhibitors (Enalaprilat, Trandolaprilate) on BFU-E Colony Formation in HD Patients and Controls}

Losartan produced a dose-dependent inhibitory effect on the BFU-E colony number in both the HD patients and the controls (fig. 2A, B). However, the ACE inhibitors did not produce a significant decrease in BFU-E colony formation in either the HD patients or the controls. No difference in the degree of maximum inhibition was observed between the two ACE inhibitors. The percentage of BFU-E colony formation inhibition by losartan was about the same in the HD patients and the healthy volunteers. In the patients and the controls, the inhibition rates for the highest concentration $(10 \mu \mathrm{g} / \mathrm{ml})$ were 61.6 and $60.2 \%$, respectively. The percentages of BFU-E colony formation inhibition by the ACE inhibitors were similar to those for losartan in the HD patients and healthy volunteers.

\section{Effects of Angiotensin II in Combination with \\ Losartan or ACE Inhibitors (Enalaprilat, \\ Trandolaprilate) on BFU-E Growth}

To investigate the influence of angiotensin II via the AT1 receptor, angiotensin II alone or in combination with losartan was added to cultures from controls and HD patients on day 0 (fig. 3A, B). A statistically significant increase in BFU-E growth was observed in cultures stimu- 
Fig. 2. A Effects of losartan and ACE inhibitors (enalaprilat, trandolaprilate) on BFU-E formation in samples from HD patients. B Effects of losartan and in ACE inhibitors (enalaprilat, trandolaprilate) on BFU-E formation in samples from controls. Losartan produced a dose-dependent inhibitory effect on the BFU-E colony number in both the HD patients and the controls. However, the ACE inhibitors did not produce a significant decrease in BFU-E colony formation in either the HD patients or the controls. Mean number \pm SD of BFU-E present in culture of $2 \times 10^{5}$ PBMNCs from controls and HD patients is shown. ${ }^{*} \mathrm{p}<0.01$ vs. $0 \mu \mathrm{g} / \mathrm{ml}$ using two-way ANOVA.

Fig. 3. A Effects of angiotensin II (AII) and in combination with losartan (LOS) on BFU$\mathrm{E}$ growth in samples from HD patients. Stimulatory AII effect inhibited by AT1 antagonist. The AII-mediated stimulatory effect on proliferation on early erythroid progenitors was blocked by losartan. Mean number \pm SD of BFU-E present in culture of $2 \times 10^{5}$ PBMNCs is shown. $\mathrm{p}<0.01$ vs. control using two-way ANOVA. B Effects of AII and in combination with LOS on BFU-E growth in samples from controls. Mean number \pm SD of BFU-E present in culture of $2 \times 10^{5}$ PBMNCs is shown. Similar results were obtained in HD patients. $\mathrm{p}<$ 0.05 vs. control using two-way ANOVA.
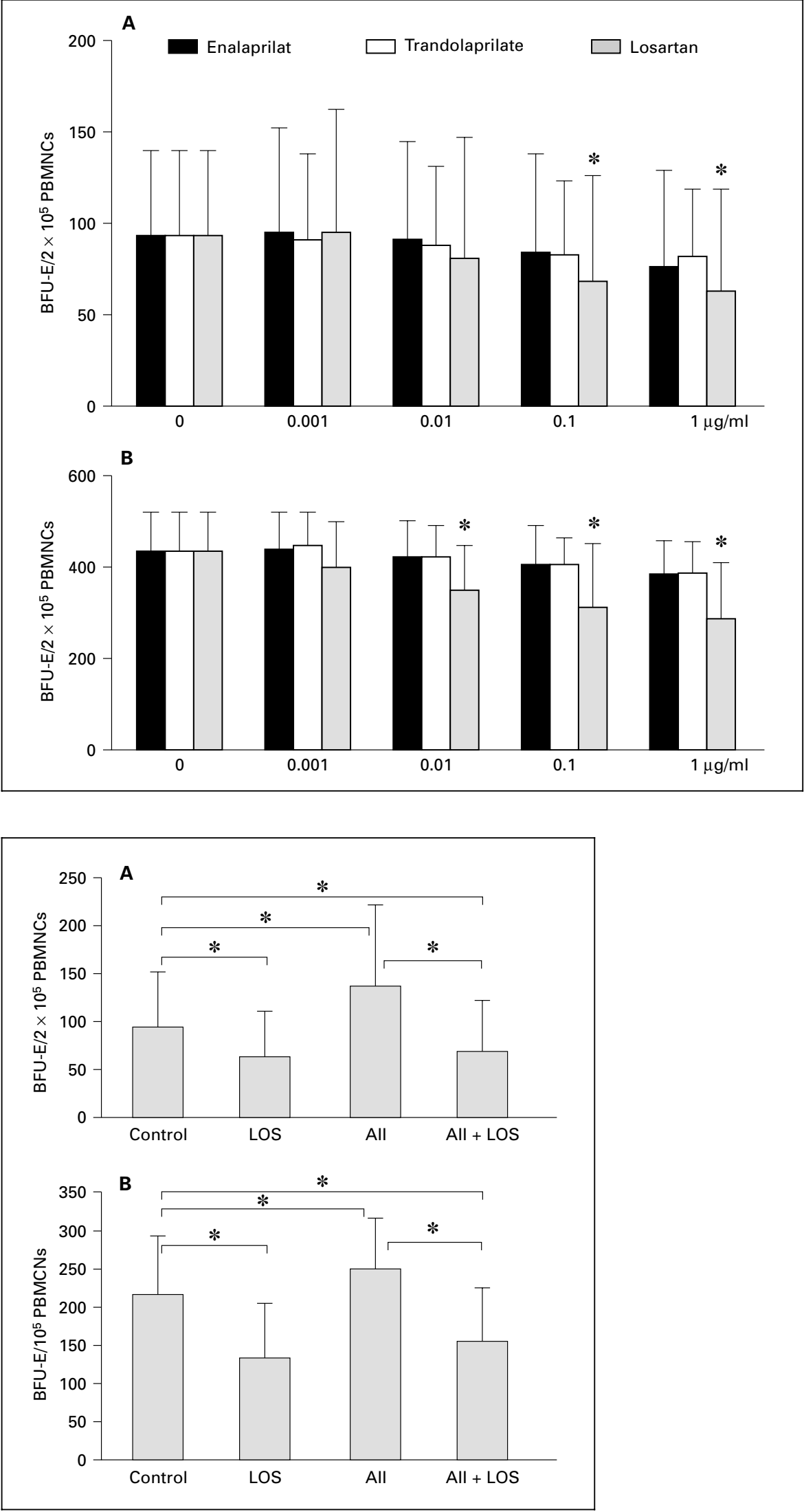
lated with angiotensin II. The number of BFU-E colonies/ dish $\left(2 \times 10^{5}\right.$ PBMNCs $)$ in the absence of drugs was considered to be the baseline value (100\%). In response to angiotensin II, BFU-E growth increased to $148 \%$ of the baseline value in HD patients ( $p<0.01$ vs. control). In the healthy volunteers, BFU-E growth increased to $115 \%$ of the baseline value $(\mathrm{p}<0.05$ vs. control).

The combination of angiotensin II and losartan showed a statistically significant difference when compared to angiotensin II alone in HD patients $(\mathrm{p}<0.01$; $68.5 \pm 61.9$ vs. $137.2 \pm 94.8 \mathrm{BFU}-\mathrm{E}$ colonies $/ 2 \times 10^{5}$ PBMNCs).

The combination of angiotensin II and the ACE inhibitors (enalaprilat or trandolaprilate) did not produce a statistically significant difference when compared to angiotensin II combined with losartan. The results for the controls and the HD patients were similar (data not shown).

\section{Discussion}

PBMNCs from HD patients produced a smaller number of BFU-Es than the cells from healthy volunteers. In the HD patients and the healthy volunteers, BFU-E growth was significantly inhibited by losartan, but the effect of ACE inhibitors was not significant. No difference in the percentage of BFU-E inhibition produced by these drugs was observed between the control and HD patient groups. Angiotensin II stimulated BFU-E growth, and our results suggest that the stimulatory effect of angiotensin II is inhibited by the AT1 receptor antagonist losartan.

We thought there are many other factors contributing to the difference in BFU-E formation between HD patients and controls. These include hematinic deficiencies (particularly iron and folic acid), hyperparathyroidism, aluminum toxicity and suppression of erythropoiesis by 'uremic inhibitors'. And several factors have been suggested as this big difference of SD between HD patients, including the nutrition, parathyroid hormone and inflammatory states (where the pro-inflammatory cytokines).

BFU-Es are motile cells found in significant numbers in PB. Although the spectrum of BFU-E in PB is probably narrower than that of BFU-E in bone marrow, consisting mostly of early, quiescent BFU-E, both sets of BFU-E exhibit a similar response to different growth factors [17]. Some studies have demonstrated that EPO is required for BFU-E growth $[15,18]$. This requirement may be due to the apparent ability of EPO to prevent cellular processes associated with apoptosis [19]. In several studies, however, BFU-E colony formation was observed even in the absence of exogenous EPO [20, 21]. Our results show that BFU-E was not observed in the absence of exogenous EPO or after the addition of more angiotensin II (data not shown). Therefore, angiotensin II may stimulate the growth of BFU-E in the presence of EPO, although this effect can be abolished by losartan. The suppressed proliferation of erythroid progenitors by these drugs in HD patients was the same as that in healthy controls, indicating that the plasma angiotensin II levels may be similar in both groups and the involvement of the renin-angiotensin system-induced suppression of proliferation also occurs in the controls. BFU-E growth significantly increased in response to angiotensin II in HD patients compared with those in controls. One possibility is that washing out uremic toxins from the whole blood of HD patients may enhance the response to angiotensin II.

Circumstantial evidence of the involvement of the renin-angiotensin system in the regulation of erythrocyte production has been reported. Recently published studies have shown that the intravenous infusion of angiotensin II in humans can increase circulating EPO levels [11, 22, 23]. The role of angiotensin II in erythropoiesis has become a subject of great interest. Stimulation of the AT1 receptor of erythroid progenitor cells by angiotensin II is believed to increase the cell mass via a mechanism that is independent of circulating EPO [15, 16]. Mrug et al. [15] studied the effect of angiotensin II on the proliferation of erythroid progenitors and reported that angiotensin II enhanced erythropoietin-stimulated erythroid proliferation in vitro. This group also showed that BFU-E colonies possess AT1 receptors, and that the effect of angiotensin II was blocked by the AT1 receptor antagonist losartan.

In our investigation, angiotensin II stimulated the growth of BFU-E; this effect was inhibited by the AT1 receptor antagonist losartan. Our data support the hypothesis that angiotensin II stimulates erythropoiesis and that this effect is mediated through the AT1 receptor. Furthermore, when losartan is added to cultures of early erythroid progenitors, the stimulatory effect of angiotensin II is inhibited. EPO, the main stimulator of erythrocyte formation, binds to a surface receptor and signals the nucleus through the Jak-STAT pathway [24]. This signaling pathway is vital, as evidenced by the embryonic lethality of Jak2 kinase knockout mice because of gross defects in erythrocyte generation $[25,26]$. Abundant evidence is available showing that angiotensin II, acting through the AT1 receptor, also stimulates Jak kinase activation and STAT nuclear translocation $[27,28]$. The activation of the AT1 receptor by its substrate has been shown to activate the Jak2/Stat, IRS2 and p70 S6 kinase pathways, com- 
mon to the activation of the EPO receptor (EPO-R) in non-erythroid cells; this raises the issue of whether AT1 and EPO receptor cross-talk on erythroid cells may have a functional role in erythropoiesis [27]. Whether or not the lack of angiotensin II-mediated Jak-STAT signaling contributes to the anemia seen in the HD patients is not clear.

Many investigations have suggested a link between ACE inhibitors and a worsening of anemia, particularly in chronic HD patients [1-4]. ACE inhibitors, recently accepted as the standard therapy for post-renal transplant erythrocytosis, may suppress erythropoiesis. AT1 receptor antagonists have also been reported to lower the hematocrit level $[10,11]$. The mechanism by which ACE inhibitor treatment leads to a decrease in the hematocrit level remains controversial. Reported studies disagree as to the role of ACE inhibitors on erythropoietin production and effectiveness. Most authors [3, 4, 8, 9] reported a significant decrease in EPO levels in patients following ACE inhibitor therapy, although some [1, 2, 5-7] did not.

The following putative mechanisms of ACE inhibitorinduced anemia have been discussed in medical literature: (1) the ACE inhibitors prevent the direct stimulatory effect of angiotensin II on the synthesis of EPO [12]; (2) ACE inhibitors increase renal plasma flow, reducing the hypoxic stimulus for EPO formation [29], and (3) the ACE inhibitors diminish likely precursors of erythropoietin by decreasing angiotensin II levels [15]. Alternatively, ACE inhibitors may have a direct pharmacological effect on red blood stem cells [30]. The pathogenesis of anemia associated with ACE inhibitor is believed to be multifactorial. Recently, a new modulator of erythropoiesis has been described, $\mathrm{N}$-acetyl-seryl-aspartyl-proline, which is an endogenous tetrapeptide that decreases the proliferation, of red cell precursors including BFU-E [31-34]. ACE inactivates this peptide, while ACE inhibitors have been shown to prevent its degradation. In addition, insulin-like growth factor (IGF)-1 significantly influences red cell production, and a study by Morrone et al. [35] suggested that IGF-1 plays a role in the ACE inhibitor-related reduction in hematocrit levels, since a direct relationship was found between the hematocrit and serum IGF-1 levels.

Our studies have shown that ACE inhibitors barely inhibit erythroid proliferation, despite the presence of full exogenous EPO unlike the actual clinical situation. If erythropoiesis depends on angiotensin II, the presence of alternative pathways, such as via cardiac chymase [36], may result in the ACE-independent formation of angiotensin II. Our results show no difference in the degree of inhibition produced by ACE inhibitors. Therefore, these different ACE inhibitors seem to have the same effect on erythropoiesis. On the other hand, ACE inhibitors may suppress a later stage of erythroid proliferation in response to increasing chemical mediators other than EPO, such as bradykinin, oxidative stress and nitric oxide; however, this hypothesis has not been tested.

Anemia associated with ACE inhibitor treatment appears to be rare, and the discontinuation of treatment is required in less than $0.1 \%$ of patients with hypertension [37]. However, Griffing and Melby [38] reported a small but significant decrease in hemoglobin associated with the prescription enalapril in healthy and hypertensive volunteers. Furthermore, in the clinical situation, that ACE inhibitors or AT1 receptor antagonists have been reported to cause anemia in HD patients, particularly those with CRF or renal transplant recipients [1-11]. Since the amount of BFU-E is much smaller in HD patients than in healthy individuals, delayed drug clearance in HD patients could cause severe BFU-E suppression.

We conclude that AT1 receptor blockade can result in the direct inhibition of erythropoiesis in HD patients and healthy volunteers in vitro.

ACE inhibitors and AT1 receptor antagonists are widely used as therapeutic agents in patients with renal failure, and many such patients are required to take both of these medications. Therefore, AT1 receptor antagonist therapy should be used with caution, and we recommend the monitoring of either hemoglobin or hematocrit levels. Further studies are needed to clarify the potential impact of the interaction of these drugs on erythropoiesis.

\section{Acknowledgment}

We thank Chugai-Pharmaceutical Co., Ltd, for the generous gift of the MethoCult. 


\section{References}

1 Hirakata H, Onoyama K, Iseki K, Kumagai H, Fujimi S, Omae T: Worsening of anemia induced by long-term use of captopril in hemodialysis patients. Am J Nephrol 1984;4:355360.

2 Hirakata H, Onoyama K, Hori K, Fujishima M: Participation of the renin-angiotensin system in the captopril-induced worsening of anemia in chronic hemodialysis patients. Clin Nephrol 1986;26:27-32.

3 Albitar S, Genin R, Fen-Chong M, Serveaux MO, Bourgeon B: High-dose enalapril impairs the response to erythropoietin treatment in haemodialysis patients. Nephrol Dial Transplant 1998;13:1206-1210.

4 Dhondt AW, Vanholder RC, Ringoir SMG Angiotensin-converting enzyme inhibitors and higher erythropoietin requirement in chronic haemodialysis patients. Nephrol Dial Transplant 1995;10:2107-2109.

5 Julian BA, Gaston RG, Barker CV, Krystal G, Diethelm AG, Curtis JJ: Erythropoiesis after withdrawal of enalapril in post-transplant erythrocytosis. Kidney Int 1994;46:13971403.

6 Perazella M, McPhedran P, Kliger A, Lorber M, Levy E, Bia MJ: Enalapril treatment of posttransplant erythrocytosis: Efficacy independent of circulating erythropoietin levels. Am J Kidney Dis 1995;26:495-500.

7 Vlahakos DV, Canzanello VJ, Madaio MP, Madias NE: Enalapril-associated anemia in renal transplant recipients treated for hypertension. Am J Kidney Dis 1991;17:199-205.

8 Gossmann J, Thürmann P, Bachmann T, Weller S, Kachel HG, Schoeppe W, Scheuermann $\mathrm{EH}$ : Mechanism of angiotensin converting enzyme inhibitor-related anemia in renal transplant recipients. Kidney Int 1996;50:973-978.

9 Danovitch G M, Jamgotchian NJ, Eggena PH, Paul W, Barrett JD, Wilkison A, Lee DBN: Angiotensin-converting enzyme inhibition in the treatment of renal transplant erythrocytosis. Transplantation 1995;60:132-137.

10 Schwarzbeck A, Wittenmeier KW, Hällfritzsch $\mathrm{U}$ : Anaemia in dialysis patients as a side-effect of sartanes. Lancet 1998;352:286.

11 Julian BA, Brantley RR, Barker CV, Stopka T, Gaston RS, Curtis JJ, Lee JJ: Losartan, an angiotensin II type 1 receptor antagonist, lowers hematocrit in posttransplant erythrocytosis. J Am Soc Nephrol 1998;9:1104-1108.

12 Gould AB, Goodman S, Dewolf R, Onesti G, Swartz C: Interrelation of the rennin system and erythropoietin in rats. J Clin Med 1980;96: 523-534.

13 Weber H, Taylor DS, Molloy CJ: Angiotensin II induces delayed mitogenesis and cellular proliferation in rat aortic smooth muscle cells. J Clin Invest 1994;93:788-798.
14 Jackson TR, Blair LAC, Marshall J, Goedert M, Hanley MR: The mas oncogene encodes an angiotensin receptor. Nature 1988;335:437440.

15 Mrug M, Stopka T, Julian BA, Prchal JF, Prchal JT: Angiotensin II stimulates proliferation of normal early erythroid progenitors. J Clin Invest 1997;100:2310-2314.

16 Gupta M, Miller BA, Ahsan N, Ulsh PJ, Zhang MY, Cheung JY, Yang HC: Expression of angiotensin II typel receptor on erythroid progenitors of patients with post-transplant erythrocytosis. Transplantation 2000;70:11881194.

17 Papayannopoulou T, Abkowitz J, Andrea DA: Biology of Erythropoiesis, Erythroid Differentiation and Maturation: Hematology. Basic Principles and Practice. New York, Churchill Livingstone, 2000, pp 202-219.

18 Heilmann E, Gottschalk D, Gottschalk I, Lisom AE: Studies in polycythemia after kidney transplantation. Clin Nephrol 1983;20:94-97.

19 Koury MJ, Bondurant MC: The molecular mechanism of erythropoietin action. Eur J Biochem 1992;210:649-663.

20 Rostaing L, Demur C, Huyn A, Durand D, Lloveras JJ, Suc JM: Erythrocytosis after renal transplant: Study of erythroid progenitors and response to enalapril. Transplant Proc1994;26: 280-281.

21 Carozzi S, Nasini MG, Salit M, Cantaluppi A, Nocera A, Valente U: $\mathrm{Ca}^{2+}$-induced modulation of erythropoiesis in polycythemic transplanted patients. Transplant Proc 1991;23: 1309-1311.

22 Freudenthaler SM, Schreeb KH, Körner T, Gleiter CH: Angiotensin II increases erythropoietin production in healthy human volunteers. Eur J Clin Invest 1999;29:816-823.

23 Gossmann J, Burkhardt R, Harder S, Lenz T, Sedlmeyer A, Klinkhardt $U$, Geiger $H$, Scheuermann EH: Angiotensin II infusion increases plasma erythropoietin levels via an angiotensin II type 1 receptor-dependent pathway. Kidney Int 2001;60:83-86.

24 Remy I, Wilson IA, Michnick SW: Erythropoietin receptor activation by a ligand-induced conformation change. Science 1999;283:990993.

25 Neubauer $\mathrm{H}$, Cumano A, Muller M, Wu H, Huffstadt U, Pfeffer K: Jak2 deficiency defines an essential developmental checkpoint in definitive hematopoiesis. Cell 1998;93:397-409.

26 Parganas E, Wang D, Stravopodis D, Topham DJ, Marine JC, Teglund S, Vanin EF, Bodner S, Colamonici OR, Deursen JM, Grosveld G, Ihle JN: Jak2 is essential for signaling through a variety of cytokine receptors. Cell 1998;93: 385-395.
27 Marrero MB, Schleffer B, Paxton WG, Heerdt L, Berk BC, Delafontaine P, Bernstein KE: Direct stimulation of Jak/STAT pathway by the angiotensin II AT1 receptor. Nature 1995; 375:247-250

28 Jayarama B, Thomas JT, Walter GT, Kathleen MC, Kenneth MB: Angiotensin II stimulates sis-inducing factor-like DNA binding activity. J Biol Chem 1994;50:31443-31449.

29 Koike H, Ito K, Miyamoto M, Nishino $\mathrm{H}$ : Effects of long-term blockade of angiotensinconverting enzyme with captopril (SQ14,225) on hemodynamics and circulating blood volume in SHR. Hypertension 1980;2:299-303.

30 Glicklich D, Kapoian T, Mian H, Gilman J, Tellis V, Croizat H: Effects of erythropoietin, angiotensin II, and angiotensin-converting enzyme inhibitor on erythroid precursors in patients with posttransplantation erythrocytosis. Transplantation 1999;68:62-66.

31 Lenfant M, Wdzieczak-Bakala J, Guittet E, Prome JC, Sotty D, Frindel E: Inhibitor of hematopoietic pluripotent stem cell proliferation. Purification and determination of its structure. Proc Natl Acad Sci USA 1989;86: 779-782.

32 Azizi M, Rousseau A, Ezan E, Guyene TT, Michelet S, Grognet JM, Lenfant M, Corvol P, Mēnard J: Acute angiotensin-converting enzyme inhibition increases the plasma level of the natural stem cell regulator $N$-acetyl-serylaspartyl-lysyl-proline. J Clin Invest 1996;97: 839-844.

33 Comte L, Lorgeot V, Vorkov L, Alleglaud A, Aldigier JC, Praloran V: Effects of the angiotensin-converting enzyme inhibitor enalapril on blood haematopoietic progenitors and acetyl- $N$-Ser-Asp-Lys-Pro. Eur J Clin Invest 1997; 27:788-790.

34 Robinson S, Lenfant M, Wdzieczak-Bakala J Melville J, Riches A: The mechanism of action of the tetrapeptide acetyl- $N$-Ser-Asp-LysPro(AcSDKP) in the control of haematopoietic stem cell proliferation. Cell Prolif 1992;25: 623-632.

35 Morrone LF, Paolo SD, Logoluso F, Schena A Stallone G, Giorgino F, Schena FP: Interference of angiotensin-converting enzyme inhibitors on erythropoiesis in kidney transplant recipients. Transplantation 1997;64:913-918.

36 Urata H, Kinoshita A, Misono KS, Bumpus FM, Husain A: Identification of a highly specific chymase as the major angiotensin II-forming enzyme in the human heart. J Biol Chem 1990;265:22348-22357.

37 American Hospital Formulary Service: Drug Information 1987. Bethesda, American Society of Hospital Pharmacists, 1987, p 817.

38 Griffing GT, Melby JC: Enalapril (MK-421) and the white cell count and haematocrit. Lancet 1982;i:1361. 